\title{
KebUdAYAAN hIBRId masa KOLONIAL DI PERKEBUNAN BATU LaWANG BANJaR
}

\section{HYBRID CULTURE OF COLONIAL PERIOD IN BATU LAWANG BANJAR PLANTATION}

\author{
Lia Nuralia \\ Balai Arkeologi Jawa Barat \\ Jl. Raya Cinunuk Km 17, Cileunyi, Bandung 40623 \\ e-mail: liabalar@yahoo.com \\ Iim Imadudin \\ Balai Pelestarian Nilai Budaya Jawa Barat \\ Jln. Cinambo No.136 Ujungberung-Bandung 42094 \\ e-mail: imadudin75@gmail.com
}

Naskah Diterima: 3 September 2018 Naskah Direvisi: 5 Desember $2018 \quad$ Naskah Disetujui: 27 Maret 2019

DOI: $10.30959 /$ patanjala.v11i1.427

\begin{abstract}
Abstrak
Pertemuan antara dua budaya berbeda (Eropa dan Asia) memunculkan satu kebudayaan campuran atau kebudayaan hibrid. Salah satunya lahir di dalam masyarakat Perkebunan Batu Lawang Banjar, yang telah berdiri sejak zaman Belanda. Apa dan bagaimana kebudayaan hibrid tersebut, akan menjadi satu permasalahan pokok, sehingga tulisan ini bertujuan mengungkap kebudayaan hibrid di Perkebunan Batu Lawang Banjar. Metode penelitian yang digunakan adalah metode penelitian survey dengan teknik pengumpulan data melalui studi literatur, wawancara sejarah lisan, dan arsip kolonial. Hasil yang diperoleh, dengan menggunakan konsep komunikasi nonverbal, bahwa kebudayaan hibrid di perkebunan peninggalan zaman Belanda, menunjukkan adanya klasifikasi sosial ekonomi yang hierarkis dan rasis. Masyarakat perkebunan khususnya terbagi ke dalam golongan Eropa dan pribumi Indonesia, yang berimbas terhadap status pekerjaan. Golongan Eropa menduduki posisi penting sebagai kelas atas (pejabat tinggi perkebunan), sedangkan golongan pribumi menjadi buruh atau karyawan perkebunan sebagai kelas bawah. Pencampuran antara kedua golongan atau kelas sosial tersebut, melahirkan kebudayaan hibrid. Pada masa sekarang kebudayaan hibrid warisan kolonial di perkebunan, dapat ditemukan bukti fisiknya berupa artefak perkebunan dan keberadaan golongan peranakan Indo-Eropa sebagai anak dari hasil perkawinan campuran, serta informasi lisan dari pelaku.
\end{abstract}

Kata kunci: kebudayaan hibrid, perkebunan Batulawang Banjar, masa kolonial.

\section{Abstrak}

The meeting between two different cultures (Europe and Asia) raises a mixed culture or hybrid culture. One of them was born in the community of Banjar Batu Lawang plantation, which had been established since the Dutch era. What and how the hybrid culture, will become the main problem, so this paper aims to reveal hybrid culture at the Banjar Batu Lawang Plantation. The research method used is the survey research method with data collection techniques through literature studies, oral history interviews, and colonial archives. The results obtained, using the concept of nonverbal communication, that hybrid culture in plantations inherited from the Dutch era, indicate a hierarchical and racist socio-economic classification. Plantation communities in particular are divided into European and indigenous Indonesian groups, which impact on employment status. The European group occupies an important position as the upper class (highranking plantation officials), while the indigenous group becomes laborers or plantation workers 
as the lower class. Mixing between the two groups or social classes gave birth to a hybrid culture. At present the colonial heritage of hybrid culture on plantations can be found in physical evidence in the form of plantation artifacts and the existence of Indo-European breeders as children of mixed marriages, as well as verbal information from the perpetrators.

Keywords: hybrid culture, Banjar Batulawang plantation, colonial period.

\section{A. PENDAHULUAN}

Kebudayaan hibrid di perkebunan pada masa kolonial Belanda dapat ditelusuri melalui bukti-bukti sejarah, yang sekarang ini masih ditemukan dalam kehidupan masyarakat perkebunan warisan zaman Belanda. Pada masa kolonial Belanda telah terjadi pertemuan dua budaya, yang kemudian saling bercampur dalam praktik kehidupan sehari-hari.

Pertemuan budaya Eropa (Barat, Belanda) dan pribumi Indonesia (Timur, Sunda) melahirkan budaya yang satu sama lain masih menampakkan ciri-ciri aslinya, dan atau melebur menjadi satu kebudayaan baru. Kebudayaan baru tersebut dikenal sebagai kebudayaan Indis. Masyarakatnya disebut masyarakat Indis. Gaya hidup masyarakat Indis ditandai dengan dibangunnya rumah-rumah mewah (landhuizen), kehidupan mewah dan boros sebagai wujud ekspresi diri, menunjukkan kekuasaan terhadap kelompok masyarakat lainnya. Kebudayaan Indis di Hindia Belanda, hidup dan berkembang masa kekuasaan VOC di abad ke-18. Kemudian surut eksistensinya di awal abad ke-20, ketika Pemerintahan Hindia Belanda mengambil alih kekuasaan. Kebudayaan Indis akhirnya hilang seiring berakhirnya kekuasaan Belanda di Indonesia dengan masuknya Jepang tahun 1942 (Soekiman, 2014: 99-100).

Kebudayaan Indis di perkebunan dengan masyarakat Indis sebagai pendukungnya, dapat ditelusuri melalui benda-benda budaya (material culture) dan informasi kesejarahan (immaterial culture), dari hasil wawancara dengan saksi atau pelaku sejarah. Dalam hal ini adalah seorang Indo-Belanda yang tinggal di kawasan permukiman emplasemen Afdeling Ciaren, Perkebunan Batulawang Ciamis. Secara administratif sekarang termasuk ke dalam wilayah Desa
Batulawang, Kecamatan Pataruman, Kota Banjar, Provinsi Jawa Barat.

Afdeling Ciaren adalah bekas lokasi Perkebunan Batu Lawang lama di daerah Banjar (Batoe Lawang Onderneming). Selanjutnya untuk membedakan Perkebunan Batulawang sekarang yang terletak di 3 wilayah administratif (Kabupaten Ciamis, Kota Banjar, Kabupaten Pangandaran), disebut Perkebunan Batu Lawang Banjar atau Batulawang Lama.

Perkebunan Batu Lawang Banjar didirikan tahun 1896 oleh Dr. Stoll (seorang pengusaha perkebunan berkebangsaan Belanda), yang dikelola oleh perusahaan milik Belanda bernama NV Java Rubber Coutchouc Maatschappij (Lampiran Besluit 1915, dalam Mulyana, 2005: 180). Dalam buku karangan Ismet (1970: 148), disebutkan Batu Lawang Onderneming, perusahaan perkebunan milik N.V. Java Caoutchouc Co te Amsterdam, dengan komoditas karet dan kopi. Pada saat ini telah menjadi bagian kebun (kebun Afdeling Ciaren), setelah di tahun 1972 bergabung dengan Perkebunan Batulawang.

Kawasan Perkebunan Batu Lawang Banjar cukup luas dan diduga sebagai cagar budaya berupa kawasan situs perkebunan peninggalan zaman Belanda. Beberapa artefak ditemukan di lokasi ini milik seorang peranakan Indo-Belanda di tahun 2016. Artefak perkebunan berupa barang milik pribadi yang sengaja disimpan di rumahnya.

Golongan peranakan atau anak-anak Indo-Eropa (Indo-Belanda) di Hindia Belanda ketika itu di abad ke-19 dan awal abad ke-20, mengelompok menjadi komunitas Indis. Golongan peranakan memiliki sebutan lain dengan arti yang sama, yaitu kaum Mestizo, anak-anak Eurasia, atau perempuan Kreol (bagi 
seorang peranakan perempuan) (Baay, 2010: 7-9). Anak-anak Eurasia ini lahir dari perkawinan campuran, baik resmi tercatat dalam hukum kaum Kolonial Belanda maupun yang tidak resmi atau lahir dari perempuan pribumi yang tidak dinikahi (anak peranakan di luar nikah/samenleven). Kedudukan anak-anak Eurasia hasil pernikahan resmi otomatis setaraf dengan orang-orang Eropa pada umumnya. Hasil pernikahan tidak resmi (di bawah tangan) mempunyai dua kemungkinan status, diakui kedudukannya dan disamakan dengan status ayahnya yang orang Belanda (Eropa), atau tidak diakui dan disamakan dengan status ibunya yang pribumi. Kemudian peranakan Indo Belanda yang lahir dari kehidupan bersama (samenleven), tidak terikat dalam pernikahan, biasanya masuk dalam anakanak hasil perkawinan "pergundikan". Status anak-anak hasil pergundikan hampir sama dengan status anak-anak hasil perkawinan di bawah tangan. Keadaan ini dapat ditelusuri dan diungkap ke permukaan melalui jejak-jejak kebudayaan campuran di perkebunan. Kebudayaan campuran yang lahir di perkebunan kemudian disebut sebagai kebudayaan hibrid masyarakat perkebunan.

Jejak-jejak kebudayaan hibrid dapat ditelusuri melalui artefak perkebunan, sebagai salah satu bentuk komunikasi nonverbal. Selain itu, juga dilengkapi dengan informasi lisan (verbal) dari hasil wawancara dengan pelaku dan saksi sejarah.

\section{B. METODE PENELITIAN}

Tulisan ini hasil penelitian dengan menggunakan metode penelitian survey permukaan dan pendekatan sejarah. Meteode survei dalam metode penelitian arkeologi terdiri dari 3 tahap, yaitu pengumpulan data (observasi), pengolahan data (deskripsi), dan penafsiran data (interpretasi) (Deetz, 1967: 8). Pengumpulan data dilakukan melalui studi literatur, wawancara (oral history interviews), dan arsip kolonial. Data dianalisis menggunakan konsep komunikasi nonverbal (non-verbal communication concept). Komunikasi nonverbal adalah bentuk komunikasi tidak langsung yang disampaikan melaui sinyalsinyal non-verbal. Sinyal non-verbal benda atau bangunan diperoleh dari bentuk atau model yang tampak secara kasat mata. Sinyal non-verbal memberi informasi tentang keadaan masa lalu, sebagai makna simbolis yang terkandung dari wujud fisiknya. Selain itu, informasi hasil wawancara juga mengandung makna tidak tersirat, sebagai informasi penting yang terkandung dari kata-kata verbalnya.

Kebudayaan hibrid masa kolonial adalah satu bentuk sejarah sosial pada masyarakat perkebunan, yang menggambarkan keseharian pekerja perkebunan atau pekerja sosial (social worker). Istilah kebudayaan hibrid awalnya digunakan dalam wacana saintifik, kemudian dalam kajian gaya arsitektur campuran (tradisional dan modern). Selanjutnya dipakai dalam analisis sosial kemasyarakatan. Masyarakat perkebunan memiliki bukti-bukti tentang kebudayaan hibrid di masa kolonial Belanda berupa material culture dan immaterial culture.

Material culture salah satunya berupa artefak perkebunan. Artefak adalah benda alam yang sengaja dibuat manusia atau menampakkan (observable) adanya jejak-jejak buatan tangan manusia, melalui teknologi pengurangan atau penambahan terhadap benda alam tersebut. Ciri penting dari artefak adalah dapat bergerak atau dapat dipindahkan (movable) dengan relatif mudah, tanpa merusak atau menghancurkan bentuk aslinya. Kemudian immaterial culture adalah kebudayaan nonfisik atau bukan benda, seperti informasi kesejarahan dan kebudayaan dalam bentuk kebudayaan hibrid, dengan keberadaan golongan peranakan atau anakanak hasil perkawinan campuran antara orang Belanda (Eropa lainnya) dan pribumi Indonesia di masa lalu. 
Artefak perkebunan dapat berperan seolah-olah benda hidup yang dapat bercerita, sehingga dapat ditemukan maknanya apabila diletakkan dalam konteks tertentu. Simbol-simbol berupa tampilan fisik artefak mengkomunikasikan informasi masa lalu sebagai tinggalan budaya perkebunan. Budaya perkebunan di masa lalu bersifat akumulatif, historis, dan dapat dipahami melalui bahasa non-verbal (culture is accumulative, historical, and perceivable) (Samovar, Porter, Daniel, 2009: 38 dalam Wulan, 2015: 222). Bahasa nonverbal berupa benda-benda budaya merupakan media, alat komunikasi, dan penyampai pesan, yang disampaikan masyarakat masa lalu kepada generasi sekarang dalam jiwa zaman yang berbeda (Nuralia, 2016: 210).

Dalam komunikasi nonverbal akan tergambar proses integrasi antara isyarat atau tanda dengan perlambangan tertentu. Komunikasi harus memperhatikan tiga hal dasar, yaitu inklusi, kontrol, dan afeksi (Schutz dalam Littlejohn and Foss, 2008). Pengertian inklusi adalah kebutuhan untuk merasa dibutuhkan, memiliki, dan merupakan bagian dari kelompoknya. Pengertian kontrol mengacu kepada hasrat untuk membentuk hubungan interaksi di antara mereka. Selanjutnya pengertian afeksi adalah kebutuhan untuk disukai dan membangun relasi sosial (Wulan, 2015: 223). Ketiga aspek dasar komunikasi tersebut dalam penerapannya berupa pesan atau sinyal nonverbal, disampaikan melalui ekspresi artefak dan lingkungannya, ekspresi kehidupan sosial tergambar dari hasil wawancara, di antaranya tentang kehidupan perkawinan campuran, nyainyai, golongan Indo-Belanda (Nuralia, 2016: 213-214).

\section{HASIL DAN BAHASAN \\ 1. Artefak Kebudayaan Hibrid Perkebunan}

Pada situs Perkebunan Batu Lawang Banjar, beberapa artefak yang mencerminkan kebudayaan hibrid adalah alat-alat makan, perlengkapan rumah tangga, dan dokumentasi foto lama. Informasi melalui wawancara diperoleh dari seorang Indo-Belanda (Ibu Djaja atau Ibu Maritje van Disco) dan pensiunan mandor besar di perkebunan (Bapak Djaja, suami Ibu Djaja).

Artefak perkebunan berupa alat-alat makan dan foto-foto lama milik Ibu Maritje yang masih ada, di antaranya: cangkir bergagang dan berceruk (foto 1), piring oval besar, piring bulat sedang, vas bunga bulat, pinggan oval bertutup, serta pinggan oval bertutup dan beralas (foto 2 dan 3). Selain itu, ada lemari baju dari kayu dua pintu dengan cermin besar dan meja marmer dengan kaki-kaki kayu (foto 4). Alat-alat makan tersebut diperkirakan diproduksi di pabrik yang sama. Di balik dasarnya ada gambar "serangkai daun" memayungi tulisan "RC" dengan tulisan Made in Japan, dan gambar dua kipas.

Barang-barang keramik tersebut lahir di masa kolonial Belanda, memiliki sebagian ciri-ciri khas keramik Eropa, walaupun made in Japan. Ciri khas keramik yang berasal dari Eropa bertekstur halus, volume tipis, motif naga, warna cerah, dan motif lainnya, seperti motif phoenix. Mengenai identitas keramik milik Ibu Maritje selanjutnya, diperlukan analisis tersendiri khusus pembahasan tentang keramik

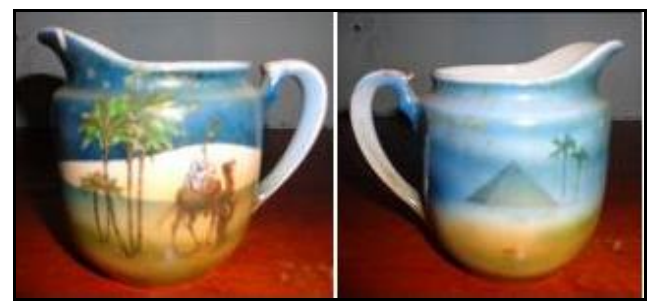

Gambar 1. Cangkir Bergagang dan

Berceruk Koleksi Pribadi Ibu Maritje Sumber: Dok. Lia Nuralia, 2016.

Istilah keramik di Indonesia secara umum adalah barang-barang yang digunakan sehari-hari terbuat dari bahan porselin dan batuan. Keramik merupakan benda pecah belah yang terbuat dari tanah 
liat (clay) bakar. Kata keramik berasal dari kata keromos (bahasa Yunani), yaitu nama Dewa Pelindung pembuat keramik. Berdasarkan bahan dan suhu pembakarannya, keramik dapat dibedakan dengan nama gerabah (earthenware), batuan (stoneware), dan porselin (porcelain). Gerabah biasanya dibakar di kisaran suhu $350^{\circ}-1000^{\circ} \mathrm{C}$, sedangkan batuan dan porselin dibakar di kisaran suhu $1150^{\circ}-1300^{\circ} \mathrm{C}$ (Maryone, 2009: 83).
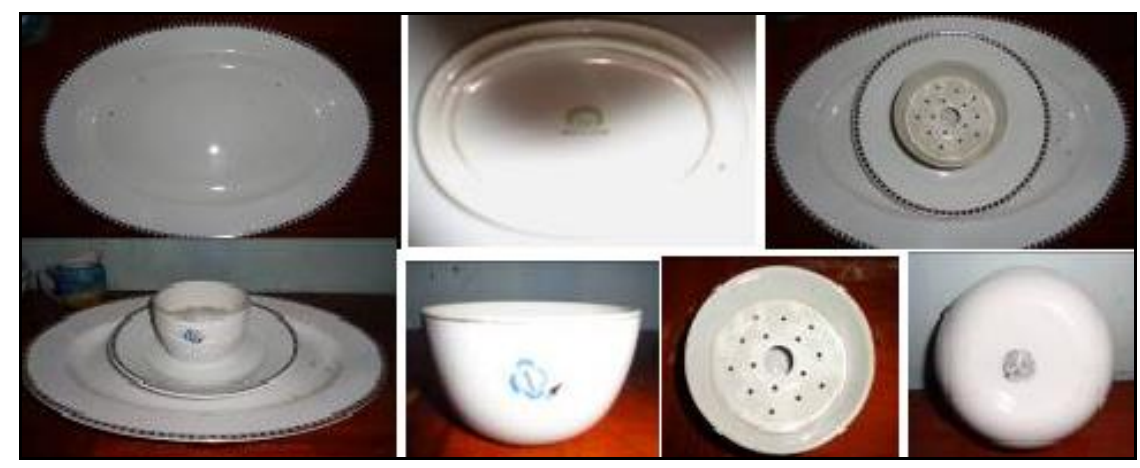

Gambar 2. Piring Oval Besar, Piring Bundar, dan Vas Bunga Koleksi Pribadi Ibu Maritje Sumber: Dok. Lia Nuralia. 2016.

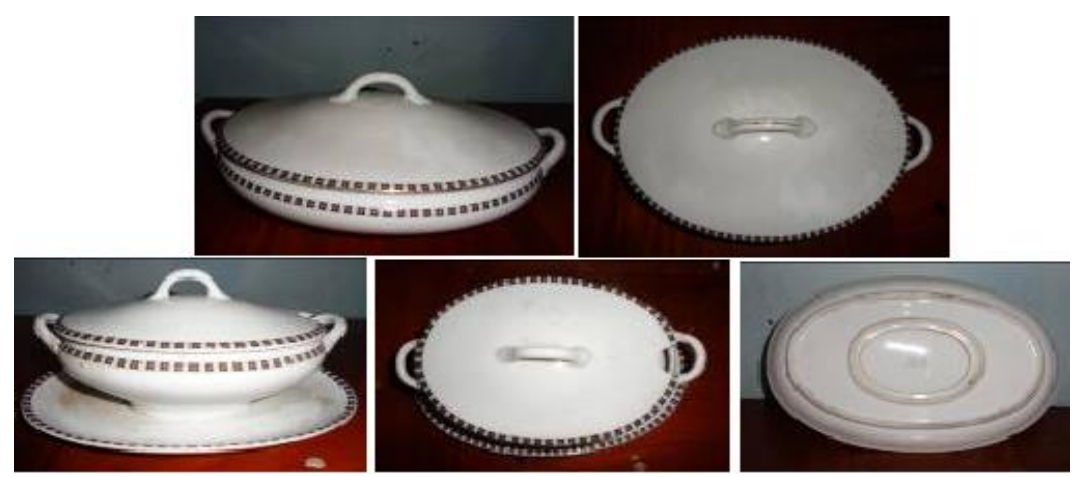

Gambar 3. Pinggan Bertutup dan Pinggan

Bertutup-Beralas Koleksi Pribadi Ibu Maritje Sumber: Dok. Lia Nuralia, 2016.

Tabel : Alat-Alat Makan, Lemari Pakaian, dan Meja Milik Ibu Maritje

\begin{tabular}{|c|c|c|c|c|c|}
\hline No. & Jenis Alat Makan & Bahan & Warna & Motif Hias & Keterangan \\
\hline 1. & $\begin{array}{l}\text { Cangkir Bergagang } \\
\text { dan Berceruk }\end{array}$ & porselin & $\begin{array}{l}\text { Putih, biru. coklat, } \\
\text { hijau. kuning }\end{array}$ & $\begin{array}{l}\text { padang pasir, } \\
\text { pohon kelapa, } \\
\text { Unta, Piramida } \\
\end{array}$ & $\begin{array}{l}\text { Hiasan di tepian, } \\
\text { badan, dasar, } \\
\text { gagang cangkir }\end{array}$ \\
\hline 2. & Piring Oval Besar & porselin & $\begin{array}{l}\text { putih, motif (coklat } \\
\text { tua, kuning mas) }\end{array}$ & $\begin{array}{c}\text { Geometris, } \\
\text { persegi kecil-kecil }\end{array}$ & $\begin{array}{l}\text { Hiasan hanya berada } \\
\text { di tepian piring }\end{array}$ \\
\hline 3. & Piring Bulat Sedang & porselin & $\begin{array}{l}\text { putih, motif (coklat } \\
\text { tua, kuning mas) }\end{array}$ & $\begin{array}{c}\text { Geometris, } \\
\text { persegi kecil-kecil }\end{array}$ & $\begin{array}{l}\text { Hiasan di tepian } \\
\text { piring }\end{array}$ \\
\hline 4. & Vas Bunga Bulat & porselin & $\begin{array}{l}\text { Putih, motif (biru, } \\
\text { hitam) }\end{array}$ & Bunga dan daun & $\begin{array}{l}\text { Hiasan ada di badan } \\
\text { dan dasar bagian luar }\end{array}$ \\
\hline 5. & Pinggan Oval Bertutup & porselin & $\begin{array}{l}\text { putih, motif (coklat } \\
\text { tua, kuning mas) }\end{array}$ & $\begin{array}{c}\text { Geometris, } \\
\text { persegi kecil-kecil }\end{array}$ & $\begin{array}{c}\text { Hiasan berada di } \\
\text { tepian pinggan dan } \\
\text { tutupnya }\end{array}$ \\
\hline 6. & $\begin{array}{c}\text { Pinggan Oval Bertutup } \\
\text { dan Beralas }\end{array}$ & porselin & $\begin{array}{l}\text { putih, motif (coklat } \\
\text { tua, kuning mas) }\end{array}$ & $\begin{array}{c}\text { Geometris, } \\
\text { persegi kecil-kecil }\end{array}$ & $\begin{array}{c}\text { Hiasan di tepian } \\
\text { pinggan, tutup, dan } \\
\text { alasnya }\end{array}$ \\
\hline 7. & $\begin{array}{l}\text { Lemari Pakaian dua } \\
\text { pintu, berlaci, berkaki }\end{array}$ & Kayu dan kaca & Coklat kayu & Garis-garis miring & $\begin{array}{l}\text { Motif hias di daun } \\
\text { pintu }\end{array}$ \\
\hline 8. & $\begin{array}{c}\text { Meja Marmer berlaci } \\
\text { dan berkaki Kayu }\end{array}$ & $\begin{array}{l}\text { Marmer, dan } \\
\text { kayu }\end{array}$ & Putih dan coklat & Tidak ada & \\
\hline
\end{tabular}




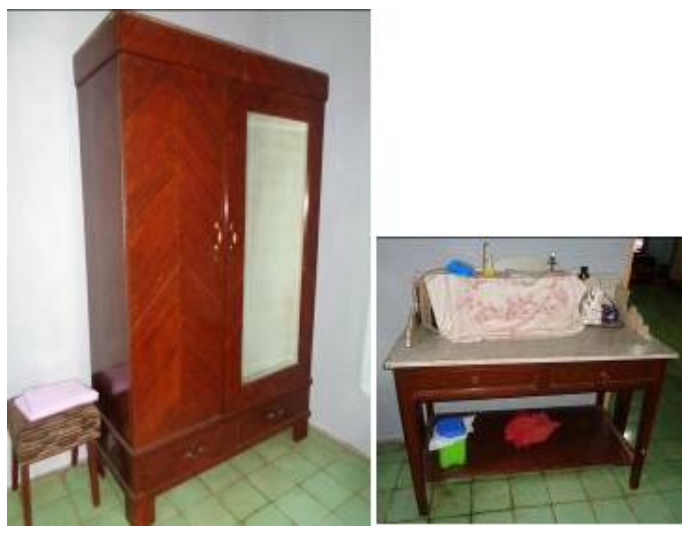

Gambar 4. Lemari Kayu dan Meja Marmer Milik Ibu Maritje,

Peninggalan Emak Sari Komarijah Sumber: Dok. Lia Nuralia, 2016.

Sementara itu, sebutan "keramik" berasal dari bahasa Inggris ceramic. Kata keramik di Indonesia lebih khusus menunjuk barang pecah belah yang diglasir dari bahan porselin dan batuan, sedangkan earthenware dan pottery disebut tembikar (Mackinnon, 1996: 1 dalam Muhaemiah, 2012: 39).

Pada masa sebelum kedatangan orang Eropa dan setelah kedatangannya, fungsi keramik mengalami pasang surut. Pada masa sebelumnya, secara umum keramik digunakan sebagai perlengkapan rumah tangga dan dalam ritus penguburan yang dilatarbelakangi oleh sistem kepercayaan, yaitu adanya kehidupan setelah mati (Maryone, 2009: 85). Setelah datang keramik dari Eropa yang dibawa orang-orang Belanda khususnya, fungsi keramik mengalami penurunan menjadi lebih profan atau tidak sakral lagi, berupa alat-alat makan dan perlengkapan rumah tangga lainnya. Kemudian bervariasi bentuknya berfungsi sebagai benda hiasan atau pajangan di rumah-rumah gedongan, para petinggi atau pejabat pemerintahan kolonial. Orang-orang Indonesia dari kalangan pribumi kelas atas, banyak meniru orang-orang Eropa dalam menata rumahnya, dengan hiasan keramik berupa vas bunga atau alat-alat lainnya.

Beberapa artefak perkebunan milik Ibu Maritje sebagian besar berupa peralatan makan terbuat dari porselin. Berdasarkan cap yang tertera di bawah piring, alat-alat makan ini buatan Jepang, tetapi tampilannya mirip dengan keramik buatan Eropa.

Artefak keramik dan porselin adalah alat-alat makan, di antaranya: cangkir bermotif gurun pasir dengan hewan unta berwarna dasar putih dan biru, piring, vas bunga, dan lain-lain berbahan sama, disimpan di dalam lemari hias di ruang tengah rumahnya. Kemudian artefak perkebunan lainnya berupa lemari pakaian dan meja marmer, yang disimpan di kamar depan. Keduanya masih digunakan seharihari. Kemudian beberapa foto lama juga ditemukan tersimpan rapi di album.

\section{Seorang Indo-Belanda di Perkebunan}

Lahirnya kebudayaan hibrid di Perkebunan Batu Lawang Banjar, selain beberapa artefak perkebunan, juga keberadaan golongan peranakan atau IndoBelanda, yaitu Ibu Maritje van Disco (foto 5). Ibu Maritje memiliki nama lengkap Maryana Maritje Ch. Disco. Ia menikah dengan seorang laki-laki pribumi, pensiunan pejabat rendahan perkebunan (mandor pribumi), yaitu Bapak Djaja bin Muhammad Subhi (foto 6). Ibu Maritje memiliki ayah seorang Belanda bernama Chornelis Frederijk van Disco atau lebih dikenal sebagai Tuan Disco (foto 7, kiri). Tuan Disco adalah pejabat tinggi Perkebunan Batu Lawang Banjar, dari tahun 1941 sampai 1958, tepatnya kepala tanaman atau sinder kepala atau employe (le Geemployeerde der Rubber onderneming "Batoelawang", di R.O Batoelawang Bandjar, West-Jawa Indonesia).

Ibu Maritje dilahirkan di Kota Banjar tahun 1941, ketika masa kekuasaan Belanda hampir berakhir. Pada saat Jepang mulai masuk di tahun 1942, Tuan Disco ditangkap dan dimasukkan ke kamp interniran Jepang. Tuan Disco berpindahpindah tempat, mulai dari Panjalu, Garut, Sumedang, Cimahi, sampai akhirnya 


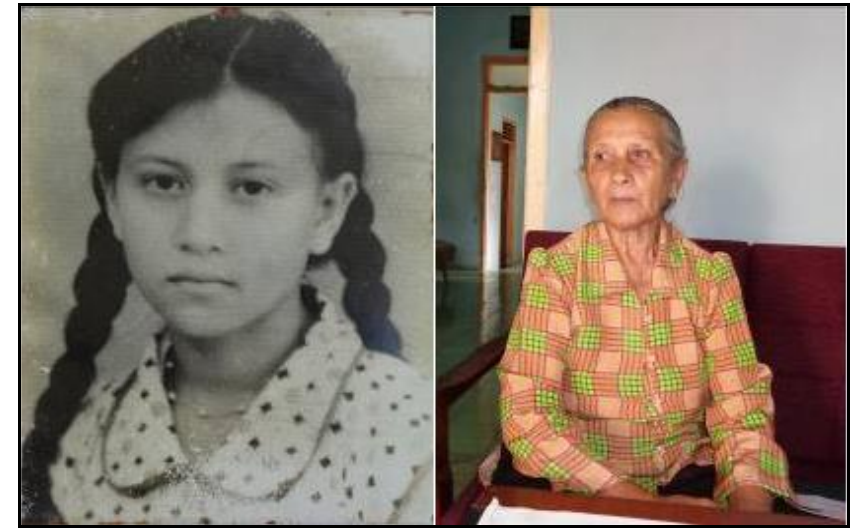

Gambar 5. Ibu Maritje masa muda dan sekarang (2016) Sumber: Koleksi Foto Pribadi Ibu Maritie

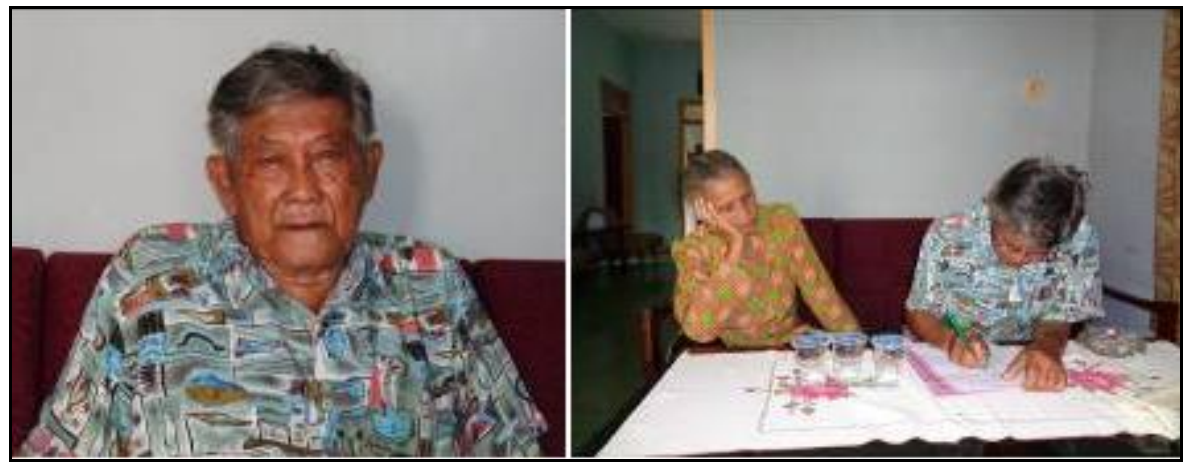

Gambar 6. Bapak Djaja dan Ibu Maritje Sumber: Dok. Lia Nuralia. 2016.
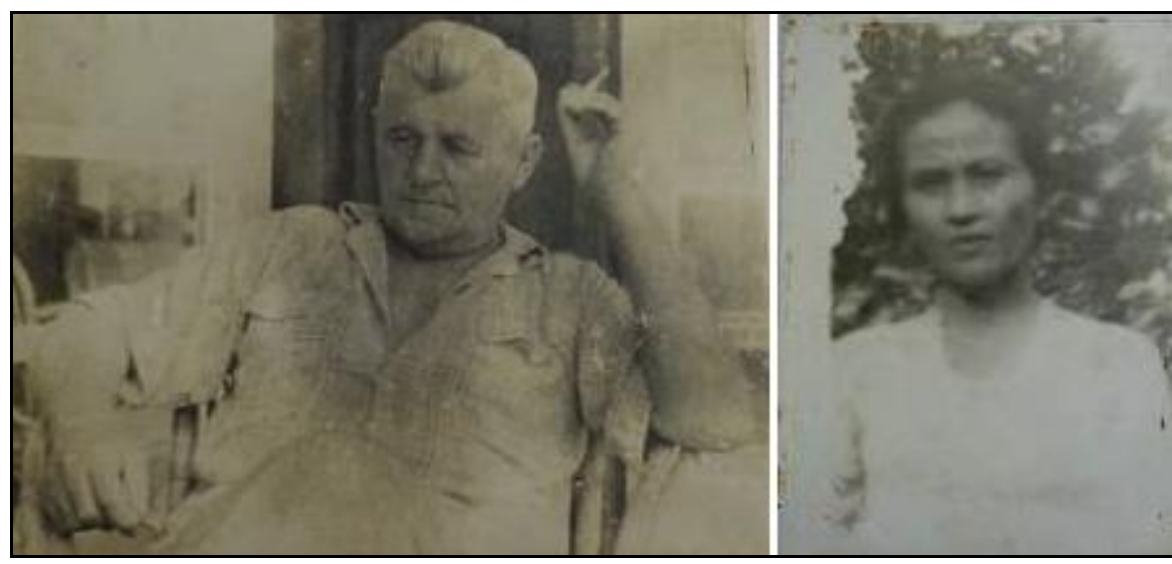

Gambar 7. Tuan Disco dan Emak Sari Komarijah Sumber: Koleksi Pribadi Ibu Maritje, 2016.

kembali ke Batulawang ketika Indonesia memasuki zaman kemerdekaan. Selama masa interniran Tuan Disco menyuruh istrinya, Emak Sari Komarijah (foto 7, kanan), menceraikannya dan menikah dengan laki-laki lain, demi kehormatan dan perlindungan yang akan diperoleh istri dan anak-anaknya. Ketika Tuan Disco kembali ke Batulawang, ia pun menikah lagi dengan perempuan pribumi lainnya. Anakanak dari Sari Komarijah, tetap mendapat perhatian dan perawatan darinya. 
Tuan Disco setelah pensiun dari perkebunan, tetap tinggal dan menetap di Indonesia, dari Batulawang pindah ke Jakarta, dan sesekali ia pergi ke Negeri Belanda dengan membawa serta anakanaknya. Pada tahun 1957, Tuan Disco meninggal di Jakarta. Kemudian Pemerintah Belanda memberinya anugerah gelar sebagai pejuang Pemerintah Belanda selama masa di kamp interniran Jepang. Anugerah ini cukup membantu keuangan keluarganya. Setelah ia meninggal, istri dan anak-anaknya memeroleh tunjangan uang yang dikirim setiap bulan.

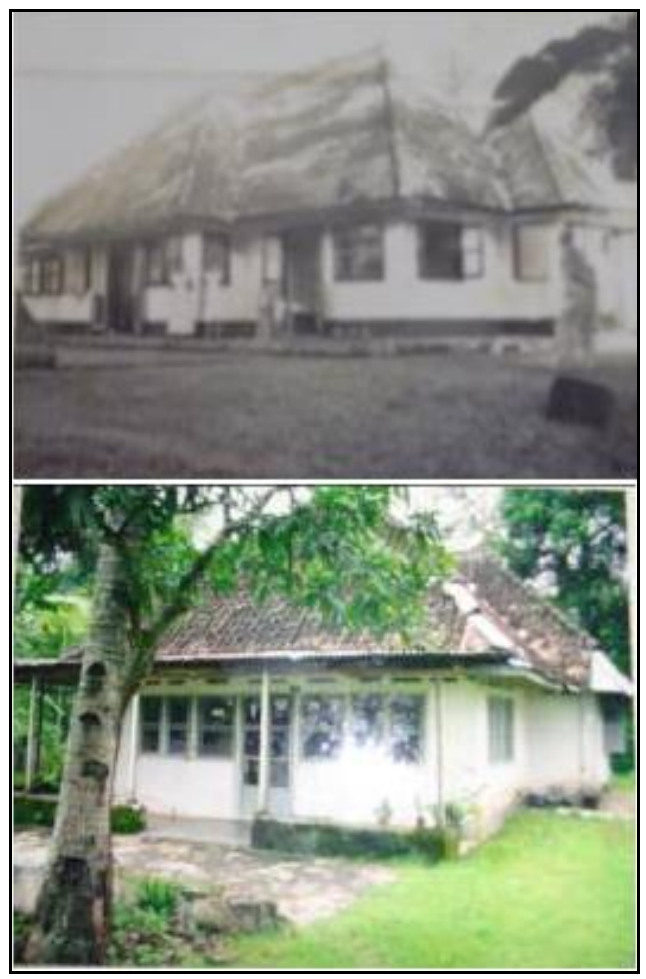

Gambar 8. Rumah Employe Perkebunan Batulawang Banjar 1940-an (Sumber: Koleksi Pribadi Ibu Maritje, 2016).

Anak-anak Tuan Disco, baik dari istri pertama maupun dari istri kedua, mendapat status dan perlakuan yang sama. Mereka diakui secara resmi dan mendapat hak-hak yang sama dalam keseharian dan kesempatan mendapat pendidikan yang baik. Hubungan di antara anak-anak yang berbeda ibu tersebut tetap baik dan berlanjut sampai sekarang. Sebagai anak- anak Indo-Belanda, mereka mendapat fasilitas hidup layak dan dapat bersekolah di sekolah untuk anak-anak Eropa yang ada di Kota Banjar ketika itu, sebagaimana anak-anak Belanda umumnya.

Tuan Disco semasa hidupnya di zaman Belanda menghabiskan waktu sebagai pejabat tinggi perkebunan, yaitu seorang employe Perkebunan Batulawang lama. Pada zaman Belanda, employe adalah posisi penting di dalam hierarki kekuasaan/struktur perkebunan. Selain memiliki keahlian di bidang tanaman, juga sebagai wiraswastawan utama dalam praktik keseharian di kebun dan pabrik. Sebagai orang nomor dua di perkebunan setelah Administratur, ia bersama keluarga mendapat fasilitas rumah layak, besar dan luas, serta memenuhi syarat-syarat kesehatan dan kenyamanan hidup. Rumah dinas Tuan Disco dan keluarga (foto 8) tampak besar dan megah dengan halaman luas, sehingga memberi kenyamanan bagi penghuninya.

Fasilitas rumah mewah dalam ukuran zaman itu, juga ditunjang dengan kegiatan-kegiatan keseharian nonkerja atau pemanfaatan waktu luang yang memberi kesenangan. Pada umumnya para pejabat perkebunan mengisi waktu luang dengan melakukan olah raga, terutama tenis lapang yang tempatnya telah disediakan perusahaan. Selain itu, mereka juga memanfaatkan waktu luang dengan sekadar ngobrol dan berkumpul bersama keluarga dan teman-teman, diselingi makan-makan atau sekadar minum teh atau minum kopi. Kegitan keseharian tersebut tampak di beberapa foto yang masih disimpan Ibu Maritje dan Bapak Djaja. Foto memperlihatkan hubungan keseharian antara orang pribumi dan Eropa. Mereka tampak berbaur dan menikmati kebersamaan (foto 9 dan foto 10). 


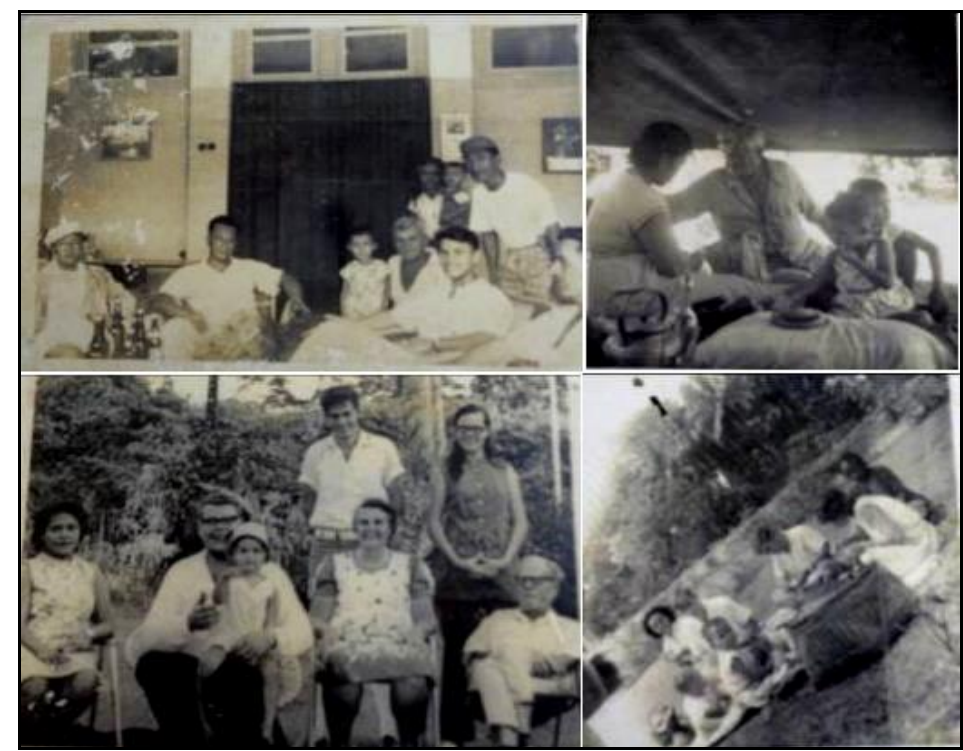

Gambar 9. Tuan Disco Bersama Keluarga dan Teman-Teman di Perkebunan Batu Lawang Banjar Tahun 1940-an Sumber: Koleksi Foto Pribadi Ibu Maritje, 2016.

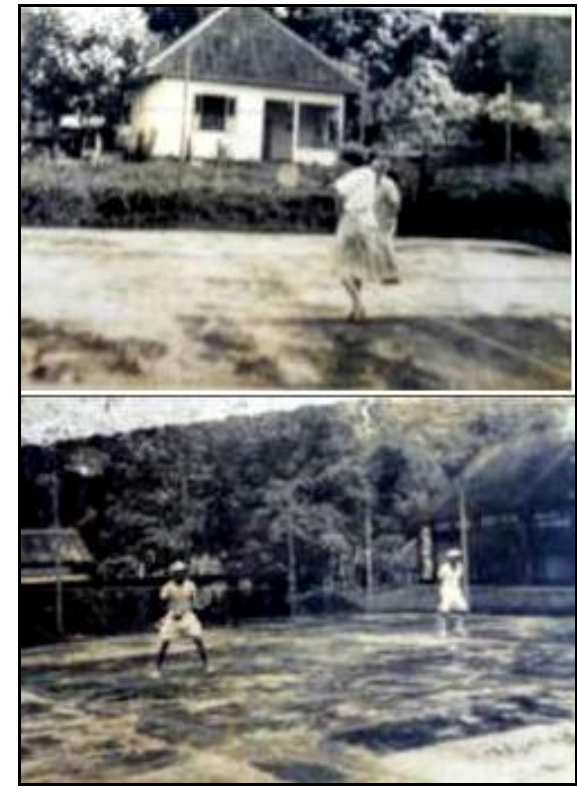

Gambar 10. Para Pejabat Perkebunan bermain Tenis Lapang di Batu Lawang Banjar 1940-an Sumber: Koleksi Pribadi Ibu Maritje, 2016.

Lapangan tenis perkebunan Batu Lawang Banjar di Desa Batulawang dahulu, kini berada di emplasemen permukiman di Afdeling Ciaren Perkebunan Batulawang, difungsikan seperti fungsi awal. Keadaannya masih seperti dahulu, dengan beberapa perbaikan dan penggantian elemen yang rusak (foto 11). Kegiatan olah raga tenis di perkebunan yang terlihat di foto 9 dan 10 , menjadi kegiatan rutin para pengelola perkebunan. Tampak bahwa yang bermain tenis adalah orang-orang yang berkulit putih, diperkirakan mereka para pejabat perkebunan sebagai golongan atas. Aktivitas di lapang tenis terlihat dalam foto lama (foto 9 dan 10) dan foto baru (foto 11). Tampak ada sedikit perubahan di lokasi lapangan, tetapi lokasinya masih tetap sama seperti lokasi awal.

Beberapa artefak perkebunan tersebut dapat memberi informasi lebih dengan menganalisisnya memakai konsep komunikasi nonverbal (non-verbal communication concept). 


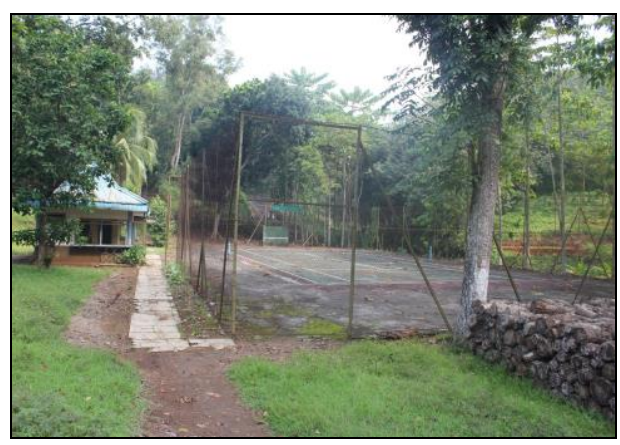

Gambar 11. Lapang Tenis di Afd. Ciaren Perkebunan Batulawang,

Sumber: Dok. Balar Bandung, 2014.

Konsep komunikasi nonverbal, seperti pendapat Schutz (dalam Littlejohn dan Foss, 2008) memiliki tiga hal dasar yang harus diperhatikan, yaitu (1) inklusi, (2) kontrol, dan (3) afeksi. Pertama, kebutuhan inklusi sebagai kebutuhan untuk merasa dibutuhkan, memiliki, dan merupakan bagian dari kelompoknya. Tuan Disco sebagai seorang employe dapat memenuhi kebutuhan dasar inklusi tersebut. Juga kebutuhan inklusi ini dirasakan juga oleh istri dan anak-anaknya. Posisinya sebagai pejabat tinggi perkebunan sangat dibutuhkan perusahaan, sebagai posisi penting yang cukup menentukan di dalam struktur dan manajemen perusahaan perkebunan. Oleh karena itu, rasa memiliki perusahaan dan menjadi bagian penting dari kelompok pejabat tinggi perkebunan (orang-orang Belanda) khususnya, dan bagian dari komunitas masyarakat perkebunan secara umum. Hal ini ditandai dengan beberapa artefak dan dokumentasi foto-foto lama. Seperti alat-alat makan yang terbuat dari keramik dengan corak tertentu (foto 1,2 , 3 ), dan foto rumah lama (foto 7) yang pernah mereka tempati, membuktikan status sosial tinggi ketika itu. Tidak semua orang dalam komunitas perkebunan zaman Belanda dapat memiliki alat-alat makan bagus dan menjadi penghuni rumah besar dan mewah, apalagi bagi perempuan pribumi.
Kebutuhan akan kontrol dan afeksi sebagai hal dasar komunikasi yang kedua dan ketiga, mengacu kepada hasrat untuk memenuhi hubungan atau interaksi di antara individu dalam komunitas perkebunan. Juga kemampuan mendapat simpati orang-orang di sekitarnya dan membangun relasi sosial. Hubungan baik di lingkungan perkebunan tampak juga dari beberapa artefak dan foto lama. Kepemilikan artefak mewah dalam ukuran zaman ketika itu, menandakan ada interaksi yang baik dengan beberapa pejabat di lingkungan perkebunan, juga dengan orang-orang di luar lingkungan perkebunan. Pada bagian dasar luar cangkir atau di baliknya ada gambar "serangkai daun" memayungi tulisan "RC" Made in Japan, dan gambar dua kipas. Alat-alat makan tersebut tidak dijual bebas, tetapi terbatas pemesanan atau hanya kalangan tertentu yang mampu membelinya. Biasanya diimpor dari luar negeri, dipasarkan melalui jaringan perdagangan khusus secara pribadi. Keadaan ini menjadi sangat eksklusif dan tidak semua orang mampu memiliki dan membelinya (Bapak Djaja dan Ibu Maritje, Batulawang, 5 Maret 2016).

Ibu Maritje sebagai anak IndoBelanda, berperan sebagai makhluk individu sekaligus makhluk sosial. Dalam kenyataannya manusia tidak dapat hidup sendiri, tetapi memerlukan manusia lain untuk berinteraksi dan bersosialisasi. Dalam kehidupan sosial tersebut kebutuhan akan pengakuan tentang keberadaannya harus bisa dipenuhi. Dengan demikian, ketiga aspek dasar komunikasi tersebut berkaitan erat dengan penampakan fisik dan nonfisik masyarakat perkebunan di masa lalu, sebagai ekspresi pribadi yang muncul ke permukaan (Nuralia, 2016: 213-214).

Ketiga aspek dasar komunikasi tersebut dalam penerapannya berupa pesan atau sinyal nonverbal, disampaikan melalui ekspresi fisik dan nonfisik tinggalan Perkebunan Batu Lawang Banjar. Ekspresi fisik berupa artefak dan lingkungannya, 
sedangkan ekspresi nonfisik berupa kehidupan sosial seperti tergambar dari hasil wawancara dan foto-foto lama tersebut. Di antaranya tentang kehidupan perkawinan campuran, peran sosial perempuan pribumi yang menjadi "nyainyai" atau istri simpanan secara hukum Belanda, serta golongan peranakan atau Indo-Belanda umumnya ketika itu. Golongan peranakan tersebut sebagian besar menempati posisi bergengsi di mata masyarakat pribumi kebanyakan, sebagai istri seorang pejabat tinggi perkebunan seperti halnya Emak Sari Komarijah atau anak Indo-Belanda sebagaimana status Ibu Maritje ketika masih kecil.

Peranakan Indo-Belanda adalah bukti fisik adanya perkawinan campuran dari dua orang yang berbeda ras dan budayanya. Ibu Maritje sebagai seorang peranakan Indo-Belanda, dari ibu seorang perempuan pribumi dan ayah seorang Belanda totok. Ras pribumi Indonesia (Sunda, Timur) dan ras Eropa (Belanda, Barat) dalam struktur penduduk Hindia Belanda berada dalam level yang tidak sama. Ras Barat menempati kelas sosial paling atas atau pertama, sedangkan ras Timur (pribumi) berada pada klasifikasi sosial paling bawah. Seperti disebutkan oleh Robert van Niel (1991: 30-38) penduduk Hindia Belanda ketika itu terbagi ke dalam 3 kelas sosial, yaitu (1) Kelas Atas adalah golongan Eropa dan atau Indo-Eropa yang dipersamakan kedudukannya, (2) Timur Asing (Cina, Arab, dan lain-lain), dan (3) Pribumi Indonesia (Sunda, Jawa dan lain-lain).

Klasifikasi sosial tersebut terjadi pada masa Hindia Belanda, yang berbanding lurus dengan status pekerjaan dan pendidikan/keahlian yang dimiliki. Secara umum juga berlaku di dalam struktur masyarakat perkebunan. Akan tetapi, struktur perkebunan lebih sederhana, awalnya terbagi ke dalam dua kelas, yaitu kelas atas dan kelas bawah, sedangkan kelas menengah sebagai jembatan antara kedua kelas lahir di kemudian hari, setelah perusahaan perkebunan mengalami perkembangan dan perluasan struktur secara vertikal dan horisontal.

Klasifikasi sosial atau struktur sosial di perkebunan menjadi 3 tingkatan, yaitu (1) Atas, (2) Menengah, dan (3) Bawah. Kelas sosial atas menempati pekerjaan sebagai pejabat tinggi perkebunan dari golongan Eropa, sedangkan kelas rendah/bawah bekerja sebagai buruh atau pekerja kasar dari golongan pribumi asli Indonesia. Adapun kelas menengah yang lahir kemudian adalah kelas menengah Eropa dan kelas menengah pribumi yang menjadi jembatan antara ras Eropa sebagai kelas atas dan ras pribumi sebagai kelas bawah (Nuralia, 2017: 9-11). Dengan demikian, perkawinan campuran atau hibriditas di perkebunan telah melahirkan kelas tersendiri dengan kebudayaan hibridnya yang khas. Anak-anak yang terlahir sebagai golongan peranakan IndoBelanda, bisa menempati posisi kelas atas apabila telah diakui dan dipersamakan kedudukannya secara hukum kolonial Belanda. Akan tetapi, menjadi termasuk golongan pribumi sebagai kelas bawah apabila mengikuti status sosial ibunya yang sebagai kelas bawah dari golongan pribumi, dan tidak diakui secara hukum kolonial adanya perkawinan di antara orang tuanya yang berbeda status sosial dan status hukumnya.

Berdasarkan struktur sosial khas perkebunan tersebut, kedudukan Ibu Maritje telah dipersamakan dengan golongan kelas atas penduduk Hindia Belanda ketika itu, karena mengikuti status ayahnya yang Belanda dan pejabat tinggi perkebunan. Ibunya yang pribumi asli Indonesia (Sunda), yang bekerja sebagai buruh kebun, telah pula dinikahi secara resmi, sehingga status sosialnya pun ikut naik ke kelas atas. Dengan status sosial tinggi tersebut, Ibu Maritje kecil bisa mengecap pendidikan dan kehidupan keseharian yang lebih baik dibanding dengan anak-anak buruh kebun lainnya.

Berdasarkan keberadaan golongan peranakan masyarakat perkebunan, 
dokumentasi foto lama, serta artefak perkebunan dan informasi lisan dari seorang Indo-Belanda, makna di balik material culture dan immaterial culture tersebut bisa bercerita lebih banyak lagi. Makna simbolis di baliknya menunjukkan nilai-nilai lama (nilai-nilai kolonial) yang menjadi gaya hidup masyarakat perkebunan. Para pejabat perkebunan di Ciamis khususnya dan di Priangan pada umumnya sama halnya kehidupan para menak Sunda, seperti kehidupan bupati dan jajarannya. Mereka memiliki gaya hidup tersendiri dan salah satunya dalam hal hubungan pribadi antara laki-laki dan perempuan. Kaum menak (bangsawan Sunda) Priangan pada umumnya melakukan poligami (berisitri lebih dari satu) dan konkubinasi (berselir banyak). Selain istri resmi ada juga istri-istri tidak resmi (tidak dinikahi). Istri resmi juga ada beberapa orang (sampai 4 orang istri), yang utama disebut garwa padmi, yang berikutnya disebut garwa leutik, sedangkan istri tidak resmi disebut parekan atau selir (Lubis, 1998: 221). Dalam kehidupan masyarakat perkebunan, parekan atau selir ini yang banyak terjadi. Keberadaan parekan atau selir atau populer dikenal sebagai "Nyai-nyai" pribumi, sebutan untuk istri simpanan atau istri dari perkawinan campuran tidak resmi, antara laki-laki Eropa dan perempuan pribumi Indonesia. Mengingat perkawinan campuran tersebut berada pada situasi kolonial, hubungan tersebut merupakan percampuran dua budaya antara Barat dan Timur, sebagai penjajah dan anak jajahan, sebagai orang kulit putih dan orang dengan kulit berwarna (sawo matang/coklat).

Situasi kolonial menempatkan posisi istri simpanan, di perkotaan atau di perkebunan berada pada status tidak jelas dan terkadang memalukan. Bagi laki-laki Eropa dan perempuan pribumi, hubungan laki-laki-perempuan tersebut menjadi olokolokan atau ejekan. Laki-laki Eropa sebagai bujangan tidak laku atau tidak mampu memiliki perempuan yang sederajat dengan golongannya. Perempuan pribumi dianggap telah memberi "aib" bagi keluarganya, karena dijadikan istri simpanan yang tidak dinikahi secara resmi. Ada juga yang beranggapan sebaliknya, bahwa menjadi perempuan simpanan si Tuan Kulit Putih dapat mengangkat derajat kehidupannya. Sebagai nyonya di rumah si Tuan tersebut menjadikan perempuan pribumi terpandang di mata penduduk setempat, karena status baru yang diembannya sebagai istri simpanan atau "selir" si Tuan Belanda, menampakkan kehidupan yang lebih sejahtera. Walaupun terkadang ada perempuan "selir" Belanda yang mengalami kehidupan buruk, karena telah terjerat kehidupan seorang "Nyai" yang malang atau terjerumus dalam pergundikan yang tidak diinginkan.

Kasus perkawinan campuran di perkebunan Batu Lawang Banjar, sedikit berbeda dengan kawin cerai yang terjadi kalangan bangsa pribumi bangsawan atau "menak" Sunda. Kawin cerai yang terjadi berakibat buruk terhadap si perempuan "selir", yang diambil ketika dibutuhkan dan dibuang ketika sudah tidak diinginkan lagi. Keadaan lebih baik terjadi di perkebunan, seperti yang dialami oleh orang tua Ibu Maritje. Laki-laki Eropa (Belanda), Tuan Disco (ayah dari Ibu Maritje), seorang pejabat tinggi perkebunan Batu Lawang Banjar. Ia menikahi perempuan pribumi, Emak Sari Komarijah, seorang buruh kebun di Perkebunan Batu Lawang Banjar. Emak Sari Komarijah (ibu dari Ibu Maritje) adalah istri yang dinikahi pertama kali. Kemudian diceraikan ketika Tuan Disco harus meninggalkannya ke kamp interniran Jepang. Perceraian ini terjadi demi menjaga martabat dan kehormatan istri dan anak-anaknya. Tuan Disco kemudian menikah lagi dengan perempuan pribumi juga (pernikahan kedua), setelah bebas dari kamp interniran. Pada saat itu bekas istrinya telah menikah terlebih dahulu dengan laki-laki pribumi. Keadaan tersebut menunjukkan bahwa Tuan Disco tidak melakukan poligami, tidak memiliki selir, 
dan tidak memiliki istri orang Belanda. Ada perbedaan dengan kebiasaan menak Sunda seperti yang telah dijelaskan. Dengan demikian, perkawinan campuran dan poligami di perkebunan Batu Lawang Banjar, tidak identik poligami dan konkubinasi gaya hidup para menak Sunda tersebut. Dari foto lama (foto 9, kanan atas) tampak Tuan Disco bersama seorang perempuan pribumi (istri) dan dua orang anak kecil. Dalam foto hanya ada 1 perempuan dewasa menemaninya, menunjukkan hanya satu orang istri dalam perkawinannya.

Perkawinan campuran dengan berbagai masalah dan implikasinya terhadap kehidupan pribadi dan lingkungannya, memiliki satu hal penting apabila melihatnya dari satu perspektif tertentu. Perempuan pribumi sebagai istri tuan Belanda (Eropa) ketika itu, menjadi sosok perempuan yang memiliki kelebihan dalam peran, dibandingkan dengan perempuan-perempuan pribumi lainnya, yang tidak menjalani perkawinan campuran. Seperti peran penting yang diemban seorang istri simpanan tuan Belanda atau Nyai, yaitu sebagai mediator dua budaya, Eropa dan Asia atau budaya Barat dan budaya Timur. Penetrasi budaya Barat ke dalam budaya Timur atau sebaliknya membentuk kebudayaan baru dalam masyarakat peranakan, seperti kebiasaan makan, berbusana, berbahasa, dan gaya hidup. Budaya Eropa bagi seorang "Nyai" sudah tidak asing lagi, sehingga gaya hidup perempuan Eropa yang dianggap lebih modern, sudah menjadi kesehariannya. Gaya hidup Nyainyai tersebut juga melahirkan kebudayaan baru yang kemudian dikenal sebagai budaya Indis (Adhy dan Terry Irenewaty, 2014). Kebudayaan Indis di perkebunan Batu Lawang Banjar, tercermin dari artefak perkebunan dan foto lama, milik Ibu Maritje, seorang Indo-Belanda. Dengan demikian, kebudayaan Indis di Perkebunan Batu Lawang Banjar menjadi identik dengan kebudayaan hibrid masyarakat perkebunan masa kolonial.
Kebudayaan hibrid masyarakat perkebunan secara umum merupakan fenomena masa lalu, yang sampai sekarang masih bisa ditelusuri dan dijadikan bahan kajian kemasyarakatan. Kajian tentang masyarakat berkaitan dengan berpikir secara sosiologis. Sosiologi berkaitan dengan orang-orang yang berhubungan satu sama lain. Bagaimana manusia mengatur diri mereka sendiri dan berinteraksi satu sama lain. Bagaimana orang berperilaku dan berpikir adalah mencari pola atau struktur dalam kehidupan sosial. Strukturasi proses yang sedang berlangsung, sebagai tempat inisiasi individu yang terjalin ke dalam pola interaksi manusia, kadang-kadang membatasi segala gerak, kadang-kadang memiliki inisiatif sendiri dengan bergerak bebas (Watson, 1995: 9, 10, 11). Dalam kasus kebudayaan hibrid masa kolonial di perkebunan Batu Lawang Banjar menunjukkan ekspresi diri dua golongan sosial atau kelompok manusia dengan status sosial yang berbeda. Kebudayaan hibrid yang lahir terwujud dalam bentuk perkawinan campuran. Perkawinan campuran antara laki-laki Belanda dan perempuan pribumi Sunda adalah hasil interaksi satu sama lain. Interaksi memunculkan kehendak yang sama untuk bersatu, sehingga terjadilah perkawinan campuran tersebut.

Menurut cerita Ibu Maritje, ayahnya (Tuan disco) mengenal ibunya (Sari Komarijah) karena hubungan kerja di perkebunan. Sebagai seorang employe perkebunan Batu Lawang Banjar di zaman Belanda, ia mengenal Sari Komarijah yang ketika itu bekerja sebagai buruh kebun. Kebiasaan Tuan Disco yang selalu meninjau langsung ke lokasi kebun, membuat ia bertemu dengan para pekerja/buruhnya hampir tiap hari.

Perkawinan antara Tuan Disco dan Emak Sari Komarjah, bukan hanya bercampurnya laki-laki Belanda dan perempuan pribumi, tetapi terjadi percampuran dalam status sosial, pejabat tinggi perkebunan dan buruh perkebunan. 
Hibriditasi di perkebunan Batu Lawang Banjar dapat dikatakan sebagai percampuran antar ras dan golongan/kelas yang berbeda.

Golongan orang-orang Eropa dalam struktur perkebunan besar zaman Belanda menempati posisi penting dan status sosial tinggi. Demikian juga dengan anak-anak mereka, sebagai golongan peranakan IndoEropa dengan status yang disamakan dengan ayahnya, ketika ayahnya mengakui secara resmi anak-anak hasil perkawinan campuran tersebut. Anak-anak peranakan ini kemudian mewarisi gaya hidup orang tuanya, gaya hidup masyarakat Indis. Gaya hidup masyarakat perkebunan Batu Lawang Banjar menjadi khas, ada kesamaan dengan elite pribumi, tetapi tidak identik dengan kebiasaan memiliki banyak selir dan melakukan poligami. Kaum hibrid di perkebunan menjalankan dua budaya, yaitu kebudayaan Barat atau modern Eropa dan kebudayaan Timur sebagai budaya asli Indonesia (Nuralia, 2016: 217-218).

Kehidupan kaum hibrid, khususnya para nyai dan tuan Belanda menjadi cerita kehidupan penuh warna sepanjang sejarah. Kehidupan mereka di waktu lalu menyisakan bukti fisik di masa sekarang dengan adanya anak-anak Indo-Eropa, secara fisik menunjukkan identitas keindoan-nya. Bentuk hidung dan warna bola mata, warna kulit dan rambut, serta buktibukti fisik lainnya merupakan warisan kolonial yang tidak dapat dihilangkan (Nuralia, 2016: 217).

Bukti fisik kebudayaan hibrid di perkebunan juga dapat dilihat dari bangunan rumah tinggal/rumah dinas employe perkebunan Batu Lawang Banjar (foto 8). Rumah dengan bentuk unik dan berarsitektur Eropa dipadu unsur lokal, menunjukkan adanya percampuran dua budaya. Unsur-unsur Eropa yang telah disesuaikan dengan iklim setempat, tampak pada dinding tembok tebal dan jendela besar, juga pada tiang-tiang di teras sebagai penyangga atap, tiang-tiang semu (pilaster) di ujung masa bangunan, serta banyaknya bukaan sebagai bentuk adaptasi dengan iklim tropis basah Indonesia yang memerlukan sirkulasi udara yang baik.

Iklim tropis basah Indonesia dengan sinar matahari sepanjang tahun dan curah hujan yang tinggi, membutuhkan antisipasi keadaan rumah berupa teras di sekeliling bangunan dan banyaknya bukaan pada beberapa bagian dindingnya. Juga halaman yang luas atau ruang terbuka, sirkulasi udara lancar dan rumah menjadi terang, sehingga kelembaban udara dan curah hujan yang tinggi bisa diantisispasi. Banyaknya bukaan dan keberadaan teras memberi keleluasan keluar masuknya udara luar dan sinar matahari, serta mencegah sinar matahari masuk langsung ke dalam rumah. Sementara itu, unsur lokal yang paling menonjol terlihat bentuk atap limasan atau atap parahu kumereb dalam istilah Sunda (Nuralia, 2016: 138139). Bentuk atap limasan menjulang tinggi dengan kemiringan tertentu, membuat cucuran air hujan langsung jatuh ke tanah. Keberadaan teras atau halaman di sekeliling bangunan, sangat fungsional untuk mencegah tampias air hujan langsung masuk ke ruang dalam. Juga melindungi dari teriknya sinar matahari.

\section{PENUTUP}

Kebudayaan Hibrid di Perkebunan Batu Lawang Banjar masa kolonial ditunjukkan dengan adanya bukti fisik (material culture) dan nonfisik (immaterial culture). Bukti fisik di antaranya artefak perkebunan berupa alat-alat makan dan perlengkapan rumah tangga, serta dokumentasi foto-foto lama. Kemudian keberadaan golongan peranakan Indo Belanda. Bukti nonfisik dalam bentuk kebudayaan hibrid sebagai hasil pertemuan dari dua budaya yang berbeda (Barat dan Timur), akibat dari adanya perkawinan campuran antara laki-laki Eropa (Belanda) dan perempuan pribumi asli Indonesia (Sunda). Selain itu, adalah lahirnya struktur sosial khas perkebunan yang pernah hidup di zaman Belanda, yang sebagian masih berlaku sampai sekarang. 
Peran penting artefak perkebunan menunjukkan telah lahirnya kebudayaan hibrid, karena keberadaan artefak tersebut terkait dengan status sosial ekonomi pemiliknya dahulu. Kemudian keberadaan golongan peranakan dan struktur sosial khas perkebunan, sebagai bukti telah terjadi proses hibriditasi dalam masyarakat perkebunan di masa lalu. Bukan hanya pencampuran antara dua ras yang berbeda, Barat dan Timur, juga antara dua status sosial yang tidak sama, yaitu antara pejabat tinggi perkebunan (employe atau wakil administratur atau kepala tanaman) dan pegawai rendahan atau buruh perkebunan (buruh pabrik dan buruh kebun).

\section{DAFTAR SUMBER}

\section{Arsip}

Arschift. Rubberretate Bantardewa. Bandjar W.L. Bantardewa den 27 April 1913. Lampiran. Besluit 15 September 1915 No. 4, Koleksi Algemeen Secretarie. Jakarta: Arsip Nasional Republik Indonesia.

\section{Jurnal, Skripsi, Tesis, dan Disertasi}

Adhy, Winda Prastyaning dan Terry Irenewaty, 2014.

Peranan Nyai dalam Transformasi Modernisasi di Jawa (1870-1942), Skripsi. Yogyakarta: Jurusan Pendidikan Sejarah, Fakultas Ilmu Sosial, Universitas Negeri Yogyakarta.

Maryone, Rini. 2009.

"Fungsi Keramik Cina pada Masyarakat Biak" dalam Jurnal Papua No. 1 Vol. 2, November 2009. Halaman 83-91.

Muhaemiah. 2012.

"Temuan Keramik Asing Hasil Penelitian Arkeologi di Sulawesi Selatan" dalam Berkala Arkeologi Vol. 32. Edisi No. 1/Mei 2012. Halaman 3950.

Mulyana, Agus. 2005.

Melintasi Pegunungan, Pedataran, Hingga Rawa-Rawa: Pembangunan Jalan Kereta Api di Priangan 18781924. Disertasi. Depok: Program Studi Ilmu Sejarah, Fakultas Ilmu Budaya, Universitas Indonesia.
Nuralia, Lia. 2017.

"Struktur Sosial pada Rumah Pejabat Tinggi Perkebunan Zaman Hindia Belanda di Jawa Bagian Barat" dalam Kapata Arkeologi Vol. 13, No. 1, Juli 2017, Halaman 1-20.

2016.

Situs Perkebunan Karet Cisaga di Kabupaten Ciamis 1908-1972: Kajian Arkeologi Industri Tentang Kode Budaya Kolonial. Tesis. Depok: Program Studi Arkeologi, Fakultas Ilmu Pengetahuan Budaya, Universitas Indonesia.

Wulan, Roro Retno. 2015.

"Komuniskasi NonVerbal Bangunan Kolonial di Perkebunan Teh Jawa Barat" dalam Jurnal Sosioteknologi Vol. 14, No. 3, Desember 2015.

\section{Buku}

Baay, Reggie. 2010.

Nyai \& Pergundikan di Hindia Belanda. Terjemahan Siti Hertini Adiwoso. Depok: Komunitas Bambu.

Cassela, Eleanor Conlin. 2005.

"Social Workers: New Diretions in Industrial Archaeology". Dalam Eleanor Conlin Casella and James Symonds (Edited), Industrial Archaeology: Future Directions. USA: Springer Science and Business Media Inc. p. 3-32.

Dark, K.R. 1995.

Theoretical Archaeology. Cornell University Press.

Deetz, James. 1967.

Invitation to Archaeology. Natural History Press for The American Museum of Natural History, Garden City, NJ.

Hellwig, Tineke. 2007b.

Citra Kaum Perempuan di Hindia Belanda. Jakarta: Yayasan Obor Indonesia.

Ismet. 1970.

Daftar Tanah-Tanah Perkebunan ${ }^{2}$ di Indonesia (The List Of Estates Throughout Indonesia). Bandung: Biro Sinar C.V. 
Kartodirdjo, Sartono dan Djoko Surjo. 1991.

Sejarah Perkebunan di Indonesia:

Kajian Sosial Ekonomi. Yogyakarta: Aditya Media.

Lubis, Nina Herlina. 1998.

Kehidupan Kaum Menak Priangan 1800-1942. Bandung: Pusat Informasi Kebudayaan Sunda.

Littlejohn, Stephen and Foss. 2008.

Theories of Human Communication, 9th

Edition.: Thomson Wadsworth, Belmont.

Niel, Robert van. 2009.

Munculnya Elite Modern Indonesia. Cetakan Kedua. Jakarta: Pustaka Jaya.

Soekiman, Djoko. 2014.

Kebudayaan Indis, Dari Zaman Kompeni Sampai Revolusi. Depok: Komunitas Bambu.

Watson, Tony J. 1995.

Sociology, Work, And Industry. Third Edition. London \& New York: Rotledge.

\section{Sumber Lisan/Informan}

R. Djaja bin Muhammad Soebhi (78 tahun). 2016.

Mandor Besar Batu Lawang Banjar, Wawancara, Desa Batulawang, Kecamatan Pataruman, Kota Banjar, 53- 2016.

Maritje Maryana C.H. Disco (75 tahun). 2016. Indo-Belanda/putri C.H. Disco, Wawancara, Desa Batulawang, Kecamatan Pataruman, Kota Banjar, 53- 2016. 